\title{
Pengaruh Intervensi Tenaga Kesehatan terhadap Kepatuhan Minum Obat pada Pasien Diabetes Mellitus Tipe 2 di Indonesia: Kajian Literatur
}

(Effect of health professional's interventions on medication adherence in type 2 diabetes mellitus patients in Indonesia: a literature review)

\author{
Fransiska Indah Pratiwi* \& Aris Widayati \\ Fakultas Farmasi Universitas Sanata Dharma, Paingan, Maguwoharjo, Kec. Depok, Kabupaten Sleman, Daerah Istimewa
}

Yogyakarta

\begin{abstract}
Diabetes Mellitus (DM) therapy aims to control blood sugar levels and prevent complications. The intervention of health workers supports the compliance of DM patients in using their drugs to achieve therapeutic success. Interventions can be in the form of follow-up, reminder media, pillbox, training, booklet media, and special drug packaging. This literature review aims to describe the impact of the intervention by health workers on adherence to taking hypoglycemic drugs in type 2- DM (T2DM) patients. The literature search method is done through Google Scholar. The selected literature inclusion criteria included: 1) intervention by health workers for the treatment of T2DM patients in Indonesia, 2) an adequate intervention study design, 3) measurement of adherence parameters for hypoglycemic medication regimen and/or blood sugar levels before and after the intervention, 4) a peer-reviewed research article. The literature selection was carried out by two raters with a Kappa Cohen score of 0.939. A total of 14 selected articles were reviewed. The study results show that the incidence of T2DM occurred in women, adults, and the elderly. Interventions for health workers included home care, providing information, counseling, and using specific tools. All the reviewed articles reported improvement in adherence to medication and blood glucose controls. It can be concluded that the health professional's interventions increased adherence to hypoglycemic medications and blood glucose controls in T2DM patients.
\end{abstract}

Keywords: type 2 diabetes mellitus; adherence; health professional intervention.

ABSTRAK: Terapi penyakit Diabetes Mellitus (DM) bertujuan untuk mengontrol kadar glukosa darah dan mencegah komplikasi. Intervensi tenaga kesehatan mendukung kepatuhan penderita DM dalam menggunakan obatnya demi tercapainya keberhasilan terapi. Intervensi dapat berupa follow up, media pengingat, pillbox, pelatihan, media booklet, dan packaging obat khusus. Kajian literatur ini bertujuan memaparkan dampak intervensi tenaga kesehatan terhadap kepatuhan minum obat hipoglikemik pada pasien DM tipe 2 (DMT2). Metode pencarian literatur dilakukan melalui Google Scholar. Kriteria inklusi literatur yang dipilih yaitu artikel yang memuat: 1) intervensi tenaga kesehatan terhadap terapi pasien DMT2 di Indonesia, 2) desain studi intervensi dijelaskan secara rinci, 3) terdapat pengukuran parameter kepatuhan penggunaan obat hipoglikemik dan/atau kadar gula darah, sebelum dan setelah intervensi, 4) berupa artikel primer. Pemilihan literatur dilakukan oleh dua orang rater dengan nilai Kappa Cohen sebesar 0,939. Sejumlah 14 artikel terpilih dikaji. Hasil kajian literatur menunjukkan bahwa kejadian DMT2 banyak terjadi pada wanita, dewasa hingga lansia. Intervensi tenaga kesehatan yang dilakukan meliputi home care, pemberian informasi, konseling, maupun dengan alat bantu tertentu. Semua literatur yang dikaji menunjukkan peningkatan kepatuhan dan/atau perbaikan kadar gula darah. Oleh karena itu, dapat disimpulkan bahwa intervensi tenaga kesehatan berdampak pada peningkatan kepatuhan minum obat hipoglikemik dan berpengaruh terhadap kadar glukosa darah yang lebih baik pada pasien DMT2.

Kata kunci: diabetes mellitus tipe 2; intervensi tenaga kesehatan; kepatuhan minum obat.

\section{Pendahuluan}

Berdasarkan International Diabetes Federation (IDF), tahun 2019 Indonesia menempati urutan ke-7 di dunia dengan jumlah penderita Diabetes Mellitus (DM) terdiagnosis dokter terbanyak pada usia 20-79 tahun sebanyak 10,7 juta dan urutan ke-5 yaitu sebesar 7,9 juta penderita DM yang tidak terdiagnosa. Jumlah kematian di dunia akibat penyakit diabetes dan komplikasinya pada tahun 2019 diperkirakan sebanyak 4,2 juta. Setiap tahun jumlah penderita DM tipe 2 (DMT2) semakin bertambah. Apabila tidak dikelola dengan baik, angka kematian karena DMpun juga akan meningkat seiring bertambahnya jumlah penderita [1].

Penatalaksanaan terapi DM dapat dilakukan dengan dan/ atau

*Corresponding Author: Fransiska Indah Pratiwi Fakultas Farmasi Universitas Sanata Dharma, Krodan, Maguwoharjo, Kec. Depok, Kabupaten Sleman, Daerah Istimewa Yogyakarta, Indonesia, 5281 | Email: fransiskaip23@gmail.com

Article history

Received: 10 Juni 2021 Accepted: 01 juli 2021 Published: 05 Agust 2021

Access this article

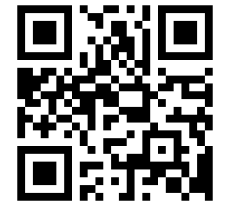


tanpa obat. Target umum penatalaksanaan terapi DMT2 yaitu tercapainya kadar glukosa terkontrol dengan $\mathrm{HbA1c}$ $<7 \%$ (53 mmol $/ \mathrm{mol}$ ). Target terapi pasien DMT2 dengan penyakit penyerta (gangguan kognitif, ginjal kronis, dan kardiovaskuler) yaitu tercapainya HbA1c 7,5\%-8\% (58$64 \mathrm{mmol} / \mathrm{mol}$ ). Prinsip pengelolaan DMT2 yaitu dengan perubahan menuju gaya hidup yang lebih sehat, terapi obat, dan pencegahan komplikasi [2].

Ketersediaan obat tanpa disertai kepatuhan minum obat tidak akan memberikan hasil yang positif. Kepatuhan minum obat diartikan dengan pasien minum obat sesuai dengan resep. Kepatuhan menggunakan obat terkait dengan konsistensi dan jumlah obat yang diminum [3]. Terapi penyakit DM merupakan terapi jangka panjang yang tidak menyembuhkan melainkan hanya untuk mengontrol kadar gula dalam darah dan untuk mencegah terjadinya komplikasi. Oleh karena itu, kepatuhan menggunakan obat menjadi nilai penting dalam keberhasilan terapi DM.

Intervensi tenaga kesehatan artinya suatu tindakan yang dilakukan tenaga kesehatan untuk menilai, memelihara, meningkatkan, dan mengubah perilaku kesehatan. Intervensi dapat berupa follow up (home care, teleconference), media pengingat (Short Message Service/SMS, WhatsApp/WA, telepon), pillbox/calendar pack (medication aids), pelatihan, media booklet, packaging obat khusus [4]. Intervensi dilakukan dengan cara tunggal atau kombinasi beberapa model intervensi. Intervensi dapat mengarah pada peningkatan pengetahuan tentang obat, keyakinan akan pengobatan, peningkatan kualitas hidup pasien, maupun tentang cara mencegah dan mengurangi kejadian yang tidak diinginkan akibat salah dalam manajemen obat [5-8]. Peran dan kemampuan tenaga kesehatan untuk memberikan intervensi kepada pasien akan berdampak kepada perubahan perilaku. Salah satu perilaku yang penting dalam menjamin keberhasilan tujuan terapi pasien adalah kepatuhan pasien dalam menjalankan terapi [5]. Di Indonesia, beberapa studi telah dilakukan untuk mengetahui pengaruh intervensi tenaga kesehatan terhadap kepatuhan minum obat pada pasien DM. Oleh karena itu, kajian literatur ini bertujuan untuk menggambarkan secara lebih komprehensif tentang dampak intervensi tenaga kesehatan terhadap kepatuhan minum obat hipoglikemik pada pasien DMT2 di Indonesia.

\section{Metode Penelitian}

\section{Pencarian Literatur}

Metode penelitian ini adalah kajian literatur/literature review. Pencarian literatur dilakukan melalui Google Scholar pada tanggal 21 Maret 2021 dengan kata kunci: intervensi, home care, pemberian informasi, konseling, kepatuhan minum obat, Diabetes Mellitus tipe 2, DMT2. Pencarian literatur dibatasi pada artikel yang dipublikasikan dalam rentang waktu sepuluh tahun terakhir, yaitu periode 2011 sampai 2021. Artikel dimasukkan dalam kajian ini jika memenuhi kriteria: 1) intervensi tenaga kesehatan terhadap terapi pasien DMT2 di Indonesia; 2) desain studi intervensi dijelaskan secara rinci, 3) terdapat pengukuran parameter kepatuhan penggunaan obat hipoglikemik dan/ atau kadar gula darah, sebelum dan setelah intervensi, 4)
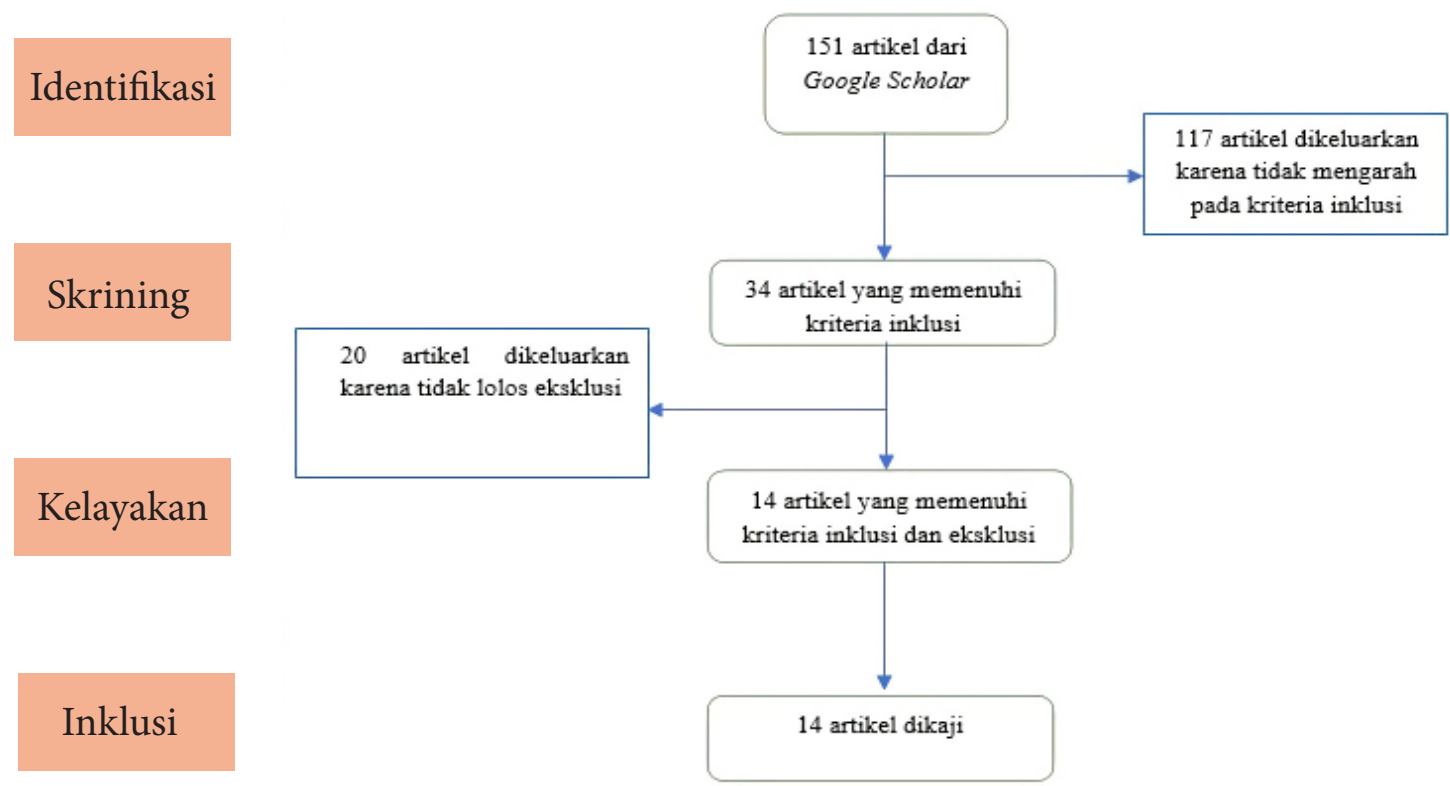

Gambar 1. Alur penelusuran dan pemilihan artikel 
berupa artikel primer. Adapun kriteria eksklusinya adalah: 1) artikel berupa skripsi, tesis, disertasi; 2) artikel publikasi tidak melalui penilaian peer-review.

\section{Pemilihan Literatur}

Pencarian artikel melalui Google Scholar dengan kata kunci yang telah ditetapkan menghasilkan 151 artikel. Skrining awal dilakukan terhadap abstrak dengan mengacu pada kriteria inklusi dan eksklusi yang telah ditetapkan. Skrining awal ini menghasilkan 34 artikel dan menyingkirkan 117 artikel karena tidak memenuhi kriteria inklusi, yaitu: bukan studi intervensi, desain studi tidak dijelaskan secara rinci, tidak mengukur kepatuhan atau kadar gula darah, dan bukan artikel hasil penelitian. Selanjutnya, seleksi dilakukan terhadap 34 artikel berdasarkan full paper. Seleksi ini dilakukan oleh dua orang peneliti (rater) secara independen mengacu pada kriteria eksklusi. Masingmasing rater menghasilkan 13 artikel dan 14 artikel. Artikel yang dieksklusi dikarenakan berupa skripsi/tesis/ disertasi atau artikel publikasi yang tidak melalui peer-review. Penghitungan nilai koefisien Kappa Cohen antara dua rater menunjukkan nilai sebesar 0,939 . Perbedaan hasil pemilihan literatur didiskusikan oleh kedua rater untuk mendapatkan kesepakatan apakah artikel tersebut diikutsertakan untuk dikaji atau tidak. Rater pertama berargumen bahwa artikel tersebut tidak memuat perhitungan nilai kepatuhan dan hanya menampilkan perbedaan kadar gula darah sebelum dan setelah intervensi. Rater kedua berpendapat meskipun artikel tersebut tidak mengukur nilai kepatuhan, namun menunjukkan kadar gula darah yang terkontrol setelah intervensi dibandingkan sebelumnya, sehingga memenuhi kriteria inklusi. Dari diskusi diperoleh kesepakatan untuk mengikutsertakan artikel tersebut, sehingga jumlah artikel yang dikaji sebanyak 14 artikel.

\section{Parameter Kajian}

Artikel yang dipilih selanjutnya dikaji dari tiga aspek berikut: 1) profil metodologi dan karakteristik

Tabel 1. Profil metodologi dan karakteristik subjek yang diteliti

\begin{tabular}{|c|c|c|c|c|c|c|}
\hline No. & Literatur & Desain & $\mathbf{N}$ & Lokasi & $\begin{array}{l}\text { Jenis kelamin } \\
\text { \&Usia rata-rata }\end{array}$ & $\begin{array}{l}\text { Tingkat } \\
\text { Pendidikan } \\
\text { rata-rata }\end{array}$ \\
\hline 1. & Literatur 1[9] & Kuasi eksperimental & 58 & $\begin{array}{c}\text { Puskesmas Srandakan Bantul, } \\
\text { Yogyakarta }\end{array}$ & $\begin{array}{l}\text { Wanita, }<65 \\
\text { tahun }\end{array}$ & - \\
\hline 2. & Literatur $2[10]$ & Kuasi eksperimental & 62 & $\begin{array}{c}\text { Puskesmas Ungaran \& Ambarawa, } \\
\text { Jawa Tengah }\end{array}$ & $\begin{array}{l}\text { Perempuan, } 56- \\
\quad 65 \text { tahun }\end{array}$ & SD-SMA \\
\hline 3. & Literatur $3[13]$ & Kuasi eksperimental & 108 & $\begin{array}{c}\text { Puskesmas Kramat Jati Jakarta } \\
\text { Timur, Jakarta }\end{array}$ & $\begin{array}{l}\text { Perempuan, 56- } \\
\quad 65 \text { tahun }\end{array}$ & SD \\
\hline 4. & Literatur 4 [14] & Kuasi eksperimental & 80 & $\begin{array}{c}\text { Puskesmas Karangsari Kabupaten } \\
\text { Cirebon, Jawa Barat }\end{array}$ & $\begin{array}{l}\text { Perempuan, } \geq 60 \\
\text { tahun }\end{array}$ & SD \\
\hline 5. & Literatur $5[15]$ & Kuasi eksperimental & 30 & Puskesmas II Denpasar Selatan, Bali & Laki-laki & SMA \\
\hline 6. & Literatur $6[11]$ & Eksperimental & 138 & $\begin{array}{c}\text { Puskesmas Kembaran I, Purwok- } \\
\text { erto Timur II dan Sumbang I, Jawa } \\
\text { Tengah }\end{array}$ & $\begin{array}{l}\text { Perempuan, 60- } \\
69 \text { tahun }\end{array}$ & SD \\
\hline 7. & Literatur $7[16]$ & Eksperimental & 60 & $\begin{array}{c}\text { RSUD A. W. Sjahranie, Kalimantan } \\
\text { Timur }\end{array}$ & $\begin{array}{l}\text { Perempuan, 56- } \\
\quad 65 \text { tahun }\end{array}$ & SMA \\
\hline 8. & Literatur 8 [17] & Randomised controlled trial & 62 & $\begin{array}{l}\text { RSUD Ulin Banjarmasin, Kalimantan } \\
\text { Selatan }\end{array}$ & $\begin{array}{l}\text { Perempuan, } 41- \\
60 \text { tahun }\end{array}$ & SMA \\
\hline 9. & Literatur $9[19]$ & Kuasi eksperimental & 100 & Puskesmas Kota Pekanbaru, Riau & $\begin{array}{l}\text { Perempuan, } 45- \\
\quad 64 \text { tahun }\end{array}$ & SMP \\
\hline 10. & Literatur 10 [18] & Randomized Controlled Trial & 40 & $\begin{array}{l}\text { Puskesmas Banjarbaru Selatan, } \\
\text { Kalimatan Selatan }\end{array}$ & $\begin{array}{l}\text { Perempuan, } \geq 60 \\
\text { tahun }\end{array}$ & SMA \\
\hline 11. & Literatur $11 \underline{[20]}$ & Kuasi eksperimental & 40 & $\begin{array}{c}\text { Puskesmas Wua-Wua Kota Kendari, } \\
\text { Sulawesi Tenggara }\end{array}$ & $\begin{array}{l}\text { Perempuan, } 46- \\
59 \text { tahun }\end{array}$ & SMP \\
\hline 12. & Literatur 12 [21] & Kuasi eksperimental & 113 & $\begin{array}{c}\text { Puskesmas di Kota Surabaya, Jawa } \\
\text { Timur }\end{array}$ & $\begin{array}{l}\text { Perempuan, 60- } \\
69 \text { tahun }\end{array}$ & SMA \\
\hline 13. & Literatur 13 [12] & Kuasi eksperimental & 70 & $\begin{array}{c}\text { Puskesmas Halmahera, Semarang, } \\
\text { Jawa Tengah }\end{array}$ & $\begin{array}{l}\text { Perempuan, } 56- \\
65 \text { tahun }\end{array}$ & SD \\
\hline 14. & Literatur 14 [22] & $\begin{array}{c}\text { Randomized Control Pretest dan } \\
\text { Post test }\end{array}$ & 30 & $\begin{array}{c}\text { Rumkital Dr. Ramelan Surabaya, } \\
\text { Jawa Timur }\end{array}$ & $\begin{array}{l}\text { Perempuan, } 60- \\
\quad 65 \text { tahun }\end{array}$ & SLTP \\
\hline
\end{tabular}


subjek penelitian, 2) profil kepatuhan menggunakan obat hipoglikemik sebelum dan sesudah intervensi, 3) profil pengendalian kadar gula darah sebelum dan sesudah intervensi. Gambar 1 menunjukkan alur penelusuran dan pemilihan artikel.

\section{Hasil dan Diskusi}

Kajian literatur ini mengkaji intervensi yang dilakukan tenaga kesehatan terhadap kepatuhan penggunaan obat hipoglikemik dan pengendalian kadar gula darah pada pasien DMT2 di Indonesia. Tabel 1 menggambarkan profil metodologi dan karakteristik subjek yang diteliti pada 14 artikel yang dikaji. Dari 14 artikel yang dikaji, ditemukan bahwa metodologi yang digunakan bervariasi antara eksperimental murni, termasuk randomized controlled trial, dan eksperimental kuasi. Lokasi intervensi sebagian besar di Puskesmas dan beberapa dilakukan di rumah sakit. Subjek yang diteliti pada ke-14 literatur yang dikaji sebagian besar adalah pasien DMT2 perempuan, dengan usia rata - rata $>40$ tahun, dengan rata - rata tingkat pendidikan antara SD sampai SMA. Tabel 2 menunjukkan kepatuhan minum obat hipoglikemik pasien DMT2 sebelum dan sesudah intervensi, dan dampak intervensi tenaga kesehatan terhadap pengendalian kadar glukosa darah. Dari beberapa literatur yang dikaji, kadar gula pasien yang mendapatkan intervensi lebih terkontrol dibandingkan yang tidak mendapatkan intervensi. Sebagian besar intervensi dilakukan oleh apoteker dan semua intervensi berdampak pada peningkatan kepatuhan penggunaan obat hipoglikemik dan kontrol kadar glukosa darah yang lebih baik.

Persebaran lokasi tempat dilakukannya intervensi pada 14 artikel yang dikaji meliputi Yogyakarta [9], Jawa Tengah [10-12], Jakarta [13], Jawa Barat [14], Bali [15], Kalimantan Timur [16], Kalimantan Selatan [17,18], Riau [19], Sulawesi Tenggara [20], Jawa Timur [21,22]. Karakteristik subjek menunjukkan penyakit DMT2 banyak dialami oleh wanita dewasa dan lansia. Namun demikian, satu artikel menggambarkan bahwa kelompok penderita DMT2 lebih banyak ditemukan pada laki-laki [15]. Risiko penyakit DM semakin meningkat dengan bertambahnya usia, obesitas, dan kekurangan aktivitas fisik [23,24], namun mulai umur $\geq 65$ tahun prevalensi DM di Indonesia cenderung menurun [25].

Dari aspek metodologi, ke-14 artikel yang dikaji menunjukkan variasi yaitu kuasi eksperimental $[9,10,12-$ 15,19-21] menggunakan pretest-posttest intervensi dengan kelompok kontrol, eksperimental [11,16], Randomised controlled trial $[17,18,22]$. Pasien yang menerima intervensi sebagian berada dalam komunitas diabetes [13,22] dan komunitas prolanis $[11,14]$. Sebagian lainnya tidak disebutkan adanya komunitas tertentu, tetapi merupakan pasien rumah sakit [16,17] dan puskesmas $[9,10,12,13,15,18-21]$.

Sebanyak 13 artikel menyebutkan pengukuran nilai kepatuhan minum obat berdasarkan pill count [16] dan kuesioner MMAS (Morisky Medication Adherence Scale) [9,10,13-15,17-20], MARS (Medication Adherence Rating Scale) [11], MGLS (Morisky, Green, Levine Adherence Scale) atau MGL MAQ (Morisky, Green, and Levine Medication Adherence Questionnaire) [12,21]. Satu artikel [22] tidak menyebutkan tingkat kepatuhan secara langsung, namun berdasarkan pengukuran kadar glukosa darah. Sepuluh artikel menunjukkan adanya data pengukuran kontrol gula darah sebagai efek pemberian intervensi [9-14,16,17,20,22]. Beberapa artikel menyebutkan waktu pengukuran kepatuhan minum obat hipoglikemik atau pengukuran kadar glukosa darah adalah satu bulan setelah pemberian intervensi $[9-13,15,17,22]$ dan 2 minggu setelah intervensi [18]. Artikel lain tidak menyebutkan waktu pengukuran setelah intervensi.

Hasil kajian menunjukkan terdapat peningkatan kepatuhan pasien minum obat hipoglikemik setelah mendapatkan intervensi [9,10,20,21,11-15,17-19]. Penilaian kepatuhan menggunakan metode pill count (sisa obat) dilakukan dengan cara menghitung sisa obat yang diresepkan setelah satu periode terapi. Pasien dinyatakan patuh menggunakan obat apabila tidak ada sisa obat dalam satu periode terapi [12,16]. Dalam kajian ini ditemukan bahwa penghitungan nilai kepatuhan minum obat dengan metode pill count dan kuesioner sama-sama memberikan hasil yang reliabel. Hal ini terlihat jelas pada satu penelitian yang menggunakan dua metode untuk mengukur kepatuhan, yaitu pill count dan kuesioner, dan memberikan hasil yang sesuai [12]. Perbedaan waktu pengukuran kepatuhan setelah intervensi dua minggu atau satu bulan tidak menunjukkan adanya perbedaan hasil. Semua intervensi tenaga kesehatan mempengaruhi kepatuhan menggunakan obat hipoglikemik.

Tim tenaga kesehatan bertanggungjawab atas terapi yang diberikan kepada pasien [26]. Intervensi merupakan suatu cara yang ditempuh untuk mempengaruhi seseorang untuk berperilaku sesuai yang diharapkan. Intervensi dari tenaga kesehatan untuk meningkatkan kepatuhan pasien dalam terapinya dapat dilakukan dengan berbagai cara diantaranya home care $[9,10,13,15]$, pemberian informasi dan edukasi $[15,16,18,20,22]$, konseling [11,12,17], maupun dengan menggunakan alat bantu tertentu $[11,19,21]$. Setiap tenaga kesehatan dapat berperan dalam 


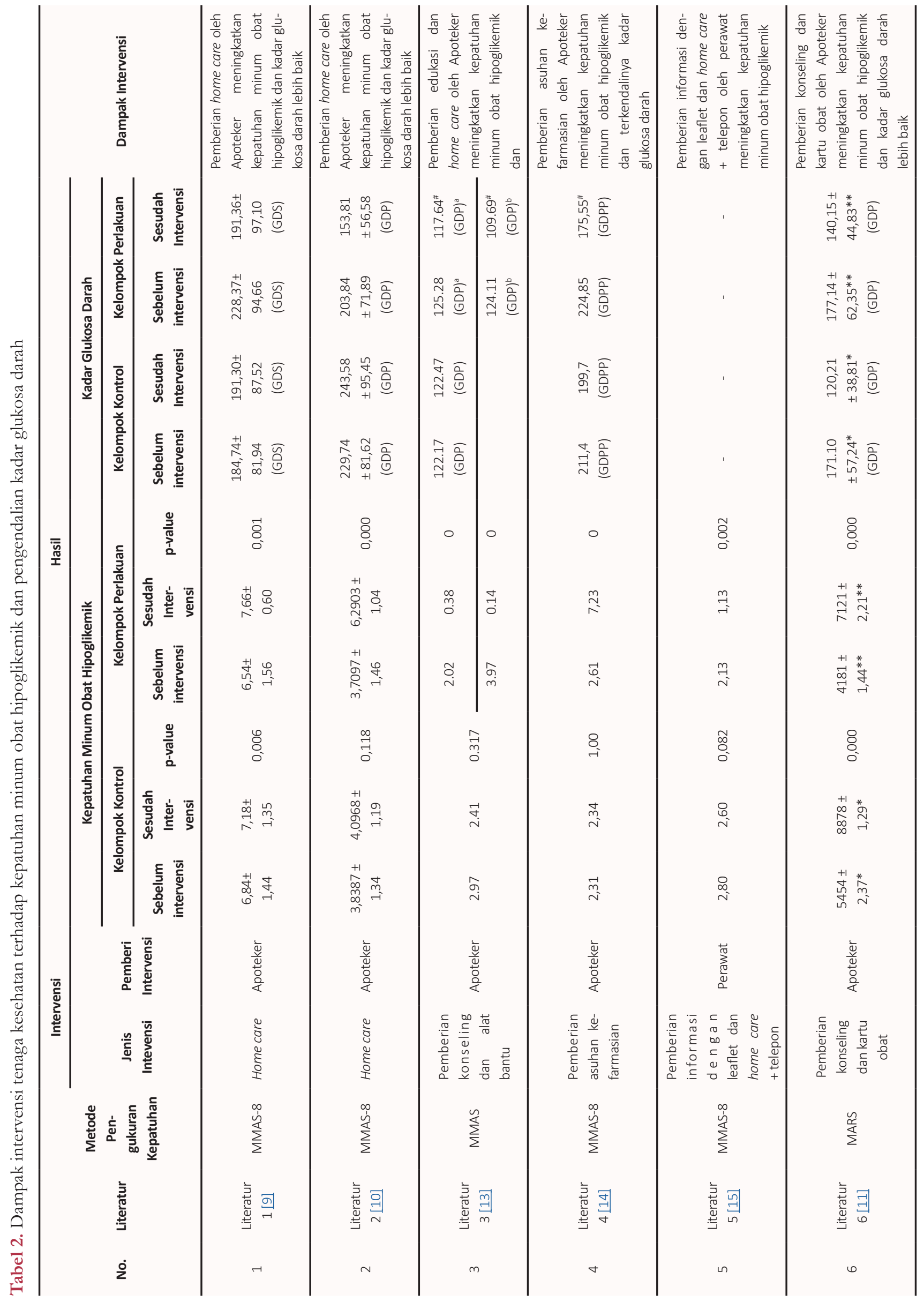




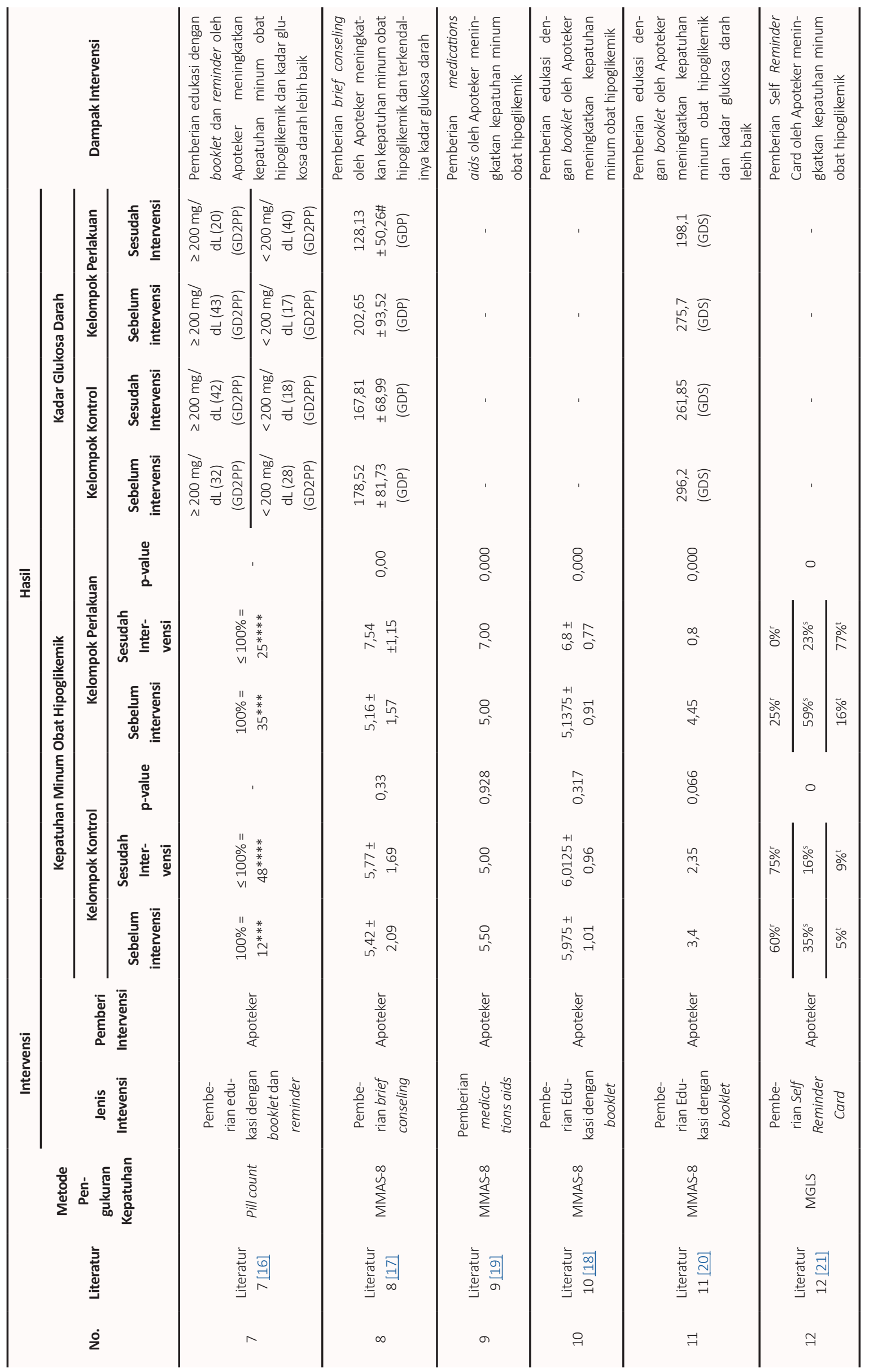




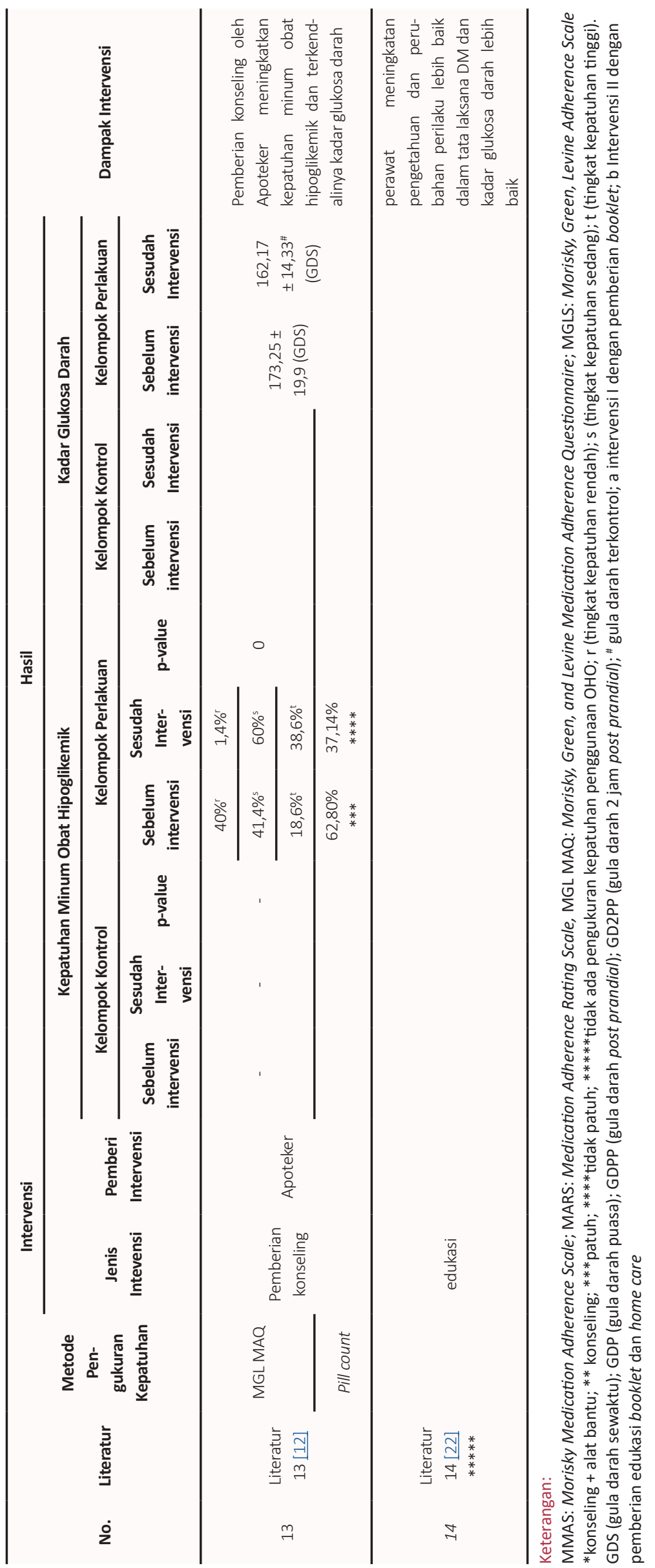


memberikan intervensi kepada pasien. Tujuan intervensi adalah perubahan perilaku hidup pasien untuk mencapai outcome terapi demi terwujudnya kualitas hidup pasien yang lebih baik. Kualitas hidup pasien dipengaruhi oleh beberapa hal diantaranya tekanan kesehatan, kenyamanan dalam pengobatan, dan gejala yang dirasakan. Edukasi dari tenaga kesehatan akan mengubah pola pikir dan pola hidup pasien. Oleh karena itulah, intervensi dari tenaga kesehatan diperlukan untuk perubahan perilaku pasien demi terwujudnya keberhasilan terapi [27].

Intervensi tentang kepatuhan minum obat sebagian besar dilakukan oleh apoteker [9,10,20,21,11-14,16-19]. Apoteker menjadi gerbang terakhir yang bertemu langsung dengan pasien dalam pelayanan kesehatan di rumah sakit maupun di puskesmas, yaitu pada saat penyerahan obat. Dengan demikian, apoteker diharapkan mampu memberikan dampak perubahan perilaku pasien ke arah yang lebih baik.

Outcome terapi DM adalah terkontrolnya kadar gula darah, dengan HbA1c $<7 \%$ (53 mmol/mol), glukosa darah preprandial kapiler 80-130 mg/dl, dan glukosa darah 1-2 jam post prandial kapiler <180 mg/dl [28]. Dengan kepatuhan pasien dalam menggunakan obat hipoglikemik sesuai regimen diharapkan dapat tercapai tujuan terapi, yaitu kadar gula dapat terkontrol dengan baik. Pada kajian literatur ini tidak ada artikel yang mengulas tentang kadar HbA1c, namun beberapa penelitian menyebutkan kadar glukosa darah sewaktu [9,12,20], glukosa darah puasa $[10,11,13,17]$, glukosa darah post prandial $[14,16,22]$.

Salah satu intervensi tenaga kesehatan pada pasien DMT2 adalah tentang perilaku pengendalian kadar glukosa darah. Pemahaman pasien yang baik akan pentingnya pengendalian kadar glukosa darah akan mempengaruhi pasien dalam mengelola penyakit DM dan terapinya. Obat dapat bermanfaat bagi pasien selama digunakan sesuai regimen dosis dan aturan serta cara pakai yang tepat. Keberhasilan terapi obat tergantung pada perilaku pasien dalam penggunaan obatnya, maupun gaya hidup sehat yang dijalaninya. Bukti keberhasilan dalam terapi obat pada pasien DM adalah tercapainya kadar glukosa pasien yang terkontrol.

Pada kajian literatur ini, beberapa penelitian telah menunjukkan bahwa pemberian intervensi oleh tenaga kesehatan berdampak pada terkontrolnya kadar glukosa darah, baik glukosa darah preprandial kapiler 80-130 mg/dl [13,17], maupun glukosa darah 1-2 jam postprandial kapiler $<180 \mathrm{mg} / \mathrm{dl}[12,14]$. Kontrol glukosa darah yang baik terlihat pada intervensi yang diberikan oleh apoteker dalam bentuk konseling [12-14,17]. Hal ini menunjukkan bahwa pemberian konseling merupakan bentuk intervensi yang efektif untuk mempengaruhi pasien patuh menggunakan obat. Dalam proses konseling, pasien belajar memahami kebutuhannya untuk patuh menggunakan obat dan dampaknya terhadap glukosa darah sehingga kesadaran untuk patuh menggunakan obat akan muncul.

Sebagian besar penelitian dalam artikel yang dikaji menunjukkan perubahan kadar glukosa yang lebih baik pada pasien yang mendapat intervensi dibandingkan yang tidak mendapatkan intervensi, meskipun perubahan ini belum menunjukkan terkontrolnya kadar glukosa darah sesuai outcome terapi yang diharapkan. Hal ini terjadi karena banyak faktor yang mempengaruhi kadar glukosa darah selain patuh minum obat, diantaranya diet, aktivitas fisik, maupun gaya hidup tidak sehat [28]. Namun demikian, dapat disimpulkan bahwa intervensi yang dilakukan oleh tenaga kesehatan dapat meningkatkan pengetahuan, sikap, dan tindakan pasien sehingga mempengaruhi kontrol glukosa darah menjadi lebih baik [6].

Seluruh penelitian pada artikel yang dikaji menunjukkan adanya dampak intervensi tenaga kesehatan terhadap kepatuhan penggunaan obat hipoglikemik, baik secara langsung maupun tidak. Terdapat satu penelitian yang tidak menunjukkan nilai kepatuhan secara langsung, tetapi hasil pengukuran kadar glukosa darah yang terkontrol menunjukkan adanya dampak baik dari pemberian intervensi. Pasien dapat mengontrol kadar glukosa darah karena adanya perubahan perilaku dalam tata laksana terapi DM yaitu adanya peningkatan kepatuhan minum obat hipoglikemik [22].

Pengobatan DM merupakan pengobatan jangka panjang yang membutuhkan ketekunan. Ketekunan berarti kemauan pasien untuk melakukan terapi sesuai durasi waktu dari mulai sampai berhentinya pengobatan. Pemahaman pasien yang baik akan arti pentingnya kepatuhan dan ketekunan dapat mengubah cara pasien memperlakukan obat yang sudah diterimanya sebagaimana mestinya. Kesesuaian pasien mengkonsumsi obat bukan hanya obat habis karena diminum, tetapi juga dengan memperhatikan seberapa dosis yang seharusnya digunakan, frekuensi minum obat, dan kapan waktu minum obat yang tepat. Intervensi yang dilakukan oleh tenaga kesehatan untuk meningkatkan kepatuhan pasien dalam menggunakan obat hipoglikemik sangat diperlukan. Dengan strategi intervensi yang tepat pasien dapat lebih memahami manajemen terapinya, serta pentingnya menjaga gaya hidup sehat untuk mendukung tercapainya outcome yang diharapkan.

Keterbatasan kajian literatur ini yaitu pencarian artikel yang dikaji terbatas pada satu mesin pencarian, yaitu Google scholar. Hal ini karena keterbatasan akses ke mesin pencari yang lain. 


\section{Kesimpulan}

Intervensi tenaga kesehatan berdampak pada peningkatan kepatuhan minum obat hipoglikemik pada pasien DMT2 dan tercapainya pengendalian kadar glukosa darah menjadi lebih baik.

\section{Ucapan Terima Kasih}

Terima kasih kami ucapkan kepada Program Studi Magister Farmasi Fakultas Farmasi Universitas Sanata Dharma, Yogyakarta dan berbagai pihak yang telah membantu selama pelaksanaan kajian literatur ini.

\section{Referensi}

[1]. Williams R, Colagiuri S, Almutairi R, Montoya PA, Basit A, Beran D, et al. IDF Diabetes Atlas [Internet]. 9th ed. International Diabetes Federation. 2019. 4-150 p. Available from: http://www.idf.org/ about-diabetes/facts-figures

[2]. American Diabetes Association. Classification and diagnosis of diabetes: Standards of medical care in Diabetes 2018. Diabetes Care. 2018;41:S13-27. https://doi.org/10.2337/dc18-S002

[3]. Vrijens B, De Geest S, Hughes DA, Przemyslaw K, Demonceau J, Ruppar T, et al. A new taxonomy for describing and defining adherence to medications. Br J Clin Pharmacol. 2012;73(5):691705. https://doi.org/10.1111/j.1365-2125.2012.04167.x

[4]. Cross AJ, Elliott RA, George J. Interventions for improving medicationtaking ability and adherence in older adults prescribed multiple medications (Protocol). Cochrane Libr. 2016;(10):1-14. https://doi. org/10.1002/14651858.CD012419.pub2

[5]. Al Rahbi HAM, Al-Sabri RM, Chitme HR. Interventions by pharmacists in out-patient pharmaceutical care. Saudi Pharm J. 2014;22(2):1016. https://doi.org/10.1016/j.jsps.2013.04.001

[6]. Suradnyana IGM, Rahem A, Aditama L. Pengaruh Patient Decision Aid terhadap Tingkat Pengetahuan, Sikap, Tindakan dan Hasil Klinis Pengobatan Penderita Diabetes Melitus Tipe 2. J Farm Klin Indones. 2018;7(2):89-98. https://doi.org/10.15416/ijcp.2018.7.2.89

[7]. Sinuraya RK, Oktrina A, Handayani NK, Destiani DP, Puspitasari IM. Pelayanan Farmasi Klinis Meningkatkan Kontrol Gula Darah Pasien. J Farm Klin Indones. 2019;8(4):271. https://doi.org/10.15416/ ijcp.2019.8.4.271

[8]. Insani WN, Lestari K, Abdulah R, Ghassani SK. Pengaruh Pelayanan Informasi Obat terhadap Keberhasilan Terapi Pasien Diabetes Melitus Tipe 2. J Farm Klin Indones. 2013;2:127-35.

[9]. Rokhman MR, Darakay CN, Raditya R. Pengaruh Pemberian Home Care oleh Apoteker pada Pasien Diabetes Mellitus. J Manaj dan Pelayanan Farm. 2015;5(3):217-24.

[10]. Hati, Karminingtyas A, Damai. Evaluasi Kepatuhan Minum Obat Pasien Diabetes Melitus Tipe 2 Di Fasilitas Kesehatan Tingkat Pertama UPTD Puskesmas Ungaran Dan UPTD Puskesmas Ambarawa Dengan Intervensi Pemberian Home Pharmacy Care. Indones J Pharm Nat Prod. 2019;02(01):19-24.

[11]. Wibowo MINA, Setiawan D, Dwi NI, Sukma FA. The Effect of Counseling and Treatment Reminder Tool to Adherence with Drug and Outcome Clinic Patients with Diabetes Mellitus and Hypertension. J Ilmu Kefarmasian Indones. 2020;18(2):169-76.

[12]. Fatiha CN, Sabiti FB. Peningkatan Kepatuhan Minum Obat Melalui Konseling Apoteker pada Pasien Diabetes Mellitus Tipe 2 di Puskesmas Halmahera Kota Semarang. JPSCR. 2021;01:41-8. https://doi.org/10.20961/jpscr.v6i1.39297
[13]. Nofrika V, Syamsuddin, Keban SA. Pharmacist Homecare and Education Effect on Type 2 DM Patient Knowledge and Obedience. Farmasains. 2016;3(2):77-81.

[14]. Rony DY, Sarnianto P, Anggriani Y. Pengaruh Asuhan Kefarmasian terhadap Kualitas Hidup Pasien Diabetes Mellitus Tipe 2 di Puskesmas Kabupaten Cirebon. Syntax Lit J IIm Indones. 2020;21(1):1-9.

[15]. Ariwisana K, Saputra MRD, Witriasih MA. Pengaruh Home Care Service terhadap Kepatuhan dalam Penatalaksanaan Diabetes Mellitus Tipe 2 pada Lansia di Wilayah Kerja Puskesmas II Denpasar Selatan. COPING. 2017;5(April):8-18.

[16]. Heraningtyas DW, Fadraersada J, Rijai L. Efektifitas Penyuluhan Pengendalian Kadar Glukosa Darah Pasien Diabetes Mellitus Tipe 2 Menggunakan Metode Reminder dan Booklet di Instalasi Rawat Jalan RSUD A.W. Sjahranie. In: Prosiding Seminar Nasional Kefarmasian Ke4. 2016. p. 90-8.

[17]. Prihandiwati E, Rahem A, Rachmawati. Pengaruh Brief Counseling terhadap Kepatuhan Minum Obat dan Kadar Gula Darah Pasien Diabetes Mellitus Tipe 2 di RSUD Ulin Banjarmasin. Calyptra. 2018;7(1):2068-85.

[18]. Srikartika VM, Akbar MR, Lingga HN. Evaluasi Intervensi Media Booklet terhadap Tingkat Pengetahuan dan Kepatuhan Pasien Diabetes Mellitus Tipe 2 di Puskesmas Banjarbaru Selatan. J Publ Kesehat Masy Indones. 2019;6(1):27-35. https://doi.org/10.20527/ ipkmi.v6i1.6874

[19]. Aryani F, Noverianti W, Muharni S. Analysis of Improvement in Medication Adherence by Using Medication Aids in Type 2 Diabetic Mellitus Outpatients in Community Health Centers Pekanbaru City. Pharm J Indones. 2019;16(02):228-43. Available from: http://jurnalnasional.ump.ac.id/index.php/PHARMACY/article/ view/4827

[20]. Sabarudin, Kasmawati H, Hamsidi R, Fitrawan L, Vitria R, Adjeng ANT. Effectiveness Booklet Usage on Compliance Level Of Taking Medication Of Patients With DM Type 2 In Wua-Wua Health Care Center Kendari City 2018. Pharmauho J Farm Sains, dan Kesehat. 2020;6(2):81. https://doi.org/10.33772/pharmauho.v6i2.11501

[21]. Fandinata SS, Ernawati I. Pengaruh Self Reminder Card terhadap Tingkat Kepatuhan Pasien dan Keberhasilan Terapi Diabetes Mellitus Tipe 2 di Puskesmas Wilayah Surabaya. SCIENTIA. 2021;11(1):49-55. Available from: http://www.jurnalscientia.org/index.php/scientia

[22]. Aini N, Fatmaningrum W, Yusuf A. Changing the Patient's Behavior in Diabetes Mellitus Management by Application Dorothy E. Johnson's Behavioral System Model. J Ners. 2011;6(1):1-10. Available from: http://210.57.222.46/index.php/JN/article/view/579/579

[23]. Siddiqui M, Khan M, Carline T. Gender Differences in Living with Diabetes Mellitus. Mater Socio Medica. 2013;25(2):140. https://doi. org/10.5455/msm.2013.25.140-142

[24]. American Diabetes Association. Standards of Medical Care in Diabetes - 2016. Diabetes Care. 2016;39.

[25]. Rasdianah N, Martodiharjo S, Andayani TM, Hakim L. Gambaran Kepatuhan Pengobatan Pasien Diabetes Mellitus Tipe 2 di Puskesmas Daerah Istimewa Yogyakarta. Indones J Clin Pharm. 2016;5(4):24957. https://doi.org/10.15416/ijcp.2016.5.4.249

[26]. Delgado-Silveira E, Fernández-Villalba EM, Freire MGM, Pérez MSA Lagranja MPC, Martí JFP. The impact of Pharmacy Intervention on the treatment of elderly multi-pathological patients. Farm Hosp. 2015;39(4):192-202. https://doi.org/10.7399/fh.2015.39.4.8329

[27]. Perwitasari DA, Adikusuma W, Rikifani S, Supadmi W, Kaptein AA. Quality of Life and Adherence of Diabetic Patients in Different Treatment Regimens. IJCP. 2014;3(4):107-13. https://doi. org/10.15416/ijcp.2014.3.4.107

[28]. Soelistijo SA, Novida H, Rudijanto A, Soewondo P, Suastika K, Manaf $A$, et al. Konsesus Pengelolaan dan Pencegahan Diabetes Melitus Tipe 2 di Indonesia 2015. Perkumpulan Endokrinologi Indonesia. Jakarta; 2015. 1-82 p. 